Article

\title{
Synthesis of Gentiooligosaccharides of Genistein and Glycitein and Their Radical Scavenging and Anti-Allergic Activity
}

\author{
Kei Shimoda ${ }^{1, *}$, Naoji Kubota ${ }^{1}$, Hatsuyuki Hamada ${ }^{2}$ and Hiroki Hamada ${ }^{3, *}$ \\ 1 Department of Chemistry, Faculty of Medicine, Oita University, 1-1 Hasama-machi, Oita 879-5593, \\ Japan \\ 2 National Institute of Fitness and Sports in Kanoya, 1 Shiromizu-cho, Kagoshima 891-2390, Japan \\ 3 Department of Life Science, Okayama University of Science, 1-1 Ridai-cho, Kita-ku, Okayama \\ 700-0005, Japan
}

* Authors to whom correspondence should be addressed; E-Mails: shimoda@med.oita-u.ac.jp (K.S.); hamada@dls.ous.ac.jp (H.H.); Tel.: +81-97-586-5606 (K.S.); +81-86-256-9473 (H.H.); Fax: +81-97-586-5619 (K.S.); +81-86-256-8468 (H.H.).

Received: 19 April 2011; in revised form: 27 May 2011 / Accepted: 2 June 2011 /

Published: 7 June 2011

\begin{abstract}
The synthesis of gentiooligosaccharides of genistein and glycitein using cultured cells of Eucalyptus perriniana as biocatalysts was investigated. The cells of E. perriniana glycosylated genistein and glycitein to give the corresponding 4'-O- $\beta$-glucosides, $7-O$ - $\beta$-glucosides, and 7-O- $\beta$-gentiobiosides, which were two new compounds. The $\beta$-glucosides of genistein and glycitein showed 2,2-diphenyl-1-picrylhydrazyl (DPPH) free-radical scavenging activity and superoxide-radical scavenging activity. On the other hand, 7-O- $\beta$-glucosides of genistein and glycitein and the 7-O- $\beta$-gentiobioside of glycitein exerted inhibitory effects on $\mathrm{IgE}$ antibody production.
\end{abstract}

Keywords: gentiooligosaccharide; genistein; glycitein; DPPH free-radical scavenging activity; superoxide-radical scavenging activity; anti-allergic activity

\section{Introduction}

The soy isoflavonoids genistein and glycitein have been recognized as natural antioxidants, and have been reported to show anti-allergic activities, such as inhibitory effects on histamine release from 
mast cells [1-5]. However, their use as food-ingredients is limited because of their water-insolubility and low absorbability after oral administration. Glycosylation using cultured cells is useful for preparing water-soluble and stable glycosides from water-insoluble and unstable organic compounds [6-11]. For example, it has been reported that glycosylation of the lipophilic flavonoid quercetin improved its absorbability after oral administration [12]. From the viewpoint of pharmacological development of isoflavonoids, their glycosylation is thus of importance. We report herein the biocatalytic glycosylation of genistein and glycitein by cultured cells of Eucalyptus perriniana to produce the corresponding 4'-O- $\beta$-glucosides, 7-O- $\beta$-glucosides, and 7-O- $\beta$-gentiobiosides. We also report their 2,2 -diphenyl-1picrylhydrazyl (DPPH) radical scavenging activity, superoxide-radical scavenging activity, and inhibitory activity for IgE antibody formation.

\section{Results and Discussion}

\subsection{Glycosylation of Genistein (1) and Glycitein (5) by Cultured Cells of E. perriniana}

After cultured cells of E. perriniana were incubated with genistein (1) for five days, the glycosylated products 2-4 were isolated from the cells by extraction with $\mathrm{MeOH}$. On the other hand, none were detected in the medium. No additional glycosylation products were detected in the $\mathrm{MeOH}$ extracts of the cells despite careful HPLC analyses. On the basis of their HRFABMS, ${ }^{1} \mathrm{H}-$ and ${ }^{13} \mathrm{C}-\mathrm{NMR}, \mathrm{H}-\mathrm{H}$ COSY, C-H COSY, and NOE-spectroscopic analyses, the products (Figure 1) were determined to be genistein 4'-O- $\beta$-glucoside $(2,5 \%)$, genistein $7-O-\beta$-glucoside $(3,41 \%)$, and genistein $7-O-\beta$-gentiobioside $(4,3 \%)$, of which 4 is a new compound.

The molecular formula of 4 was established as $\mathrm{C}_{27} \mathrm{H}_{30} \mathrm{O}_{15}$ based on its HRFABMS spectrum, which included a pseudomolecular ion $[\mathrm{M}+\mathrm{Na}]^{+}$peak at $\mathrm{m} / z 617.1488$ (calcd. 617.1482 for $\mathrm{C}_{27} \mathrm{H}_{30} \mathrm{O}_{15} \mathrm{Na}$ ). HRFABMS suggested that $\mathbf{4}$ was composed of one molecule of $\mathbf{1}$ and two hexoses. Its ${ }^{1} \mathrm{H}-\mathrm{NMR}$ spectrum showed two anomeric proton signals at $\delta 4.25(1 \mathrm{H}, d, J=8.0 \mathrm{~Hz})$ and $5.10(1 \mathrm{H}, d, J=7.6 \mathrm{~Hz})$. This suggested the presence of two $\beta$-anomers. The ${ }^{13} \mathrm{C}$-NMR spectrum included two anomeric carbon signals at $\delta 99.5$ and 102.8. The sugar component of $\mathbf{4}$ was determined to be $\beta$-D-glucopyranose based on the chemical shifts of the carbon signals. The ${ }^{13} \mathrm{C}$ resonance of C- 6 " was shifted downfield to $\delta 68.6$. Correlations were observed between the anomeric proton signal at $\delta 5.10$ (H-1") and the carbon signal at $\delta 163.0(\mathrm{C}-7)$, and between the anomeric proton signal at $\delta 4.25$ (H-1"') and the carbon signal at $\delta$ 68.6 (C-6") in the HMBC spectrum. These findings confirmed that the inner glucopyranosyl residue was attached to the phenolic hydroxyl group at C-7 of genistein (1), and that the pair of $\beta$-D-glucopyranosyl residues was 1,6-linked. Thus, 4 was identified as genistein 7-O-[6-O- $(\beta$-Dglucopyranosyl)]- $\beta$-D-glucopyranoside (7- $O$ - $\beta$-gentiobioside).

Next, glycitein (5) was subjected to the same biotransformation system. Glycoside products 6-8 were obtained from the $\mathrm{MeOH}$ extracts of the cells. The products were identified as glycitein 4'-O- $\beta$-glucoside $(6,7 \%)$, glycitein $7-O$ - $\beta$-glucoside $(7,35 \%)$, and glycitein $7-O$ - $\beta$-gentiobioside (8, $2 \%$ ) (Figure 1), of which 8 is new.

The HRFABMS spectrum of 8 included a pseudomolecular ion $[\mathrm{M}+\mathrm{Na}]^{+}$peak at $\mathrm{m} / z 631.1645$, consistent with a molecular formula of $\mathrm{C}_{28} \mathrm{H}_{32} \mathrm{O}_{15}$ (calcd. 631.1639 for $\mathrm{C}_{28} \mathrm{H}_{32} \mathrm{O}_{15} \mathrm{Na}$ ). The ${ }^{1} \mathrm{H}-\mathrm{NMR}$ spectrum of 8 included proton signals at $\delta 4.50(1 \mathrm{H}, d, J=7.6 \mathrm{~Hz})$ and $5.12(1 \mathrm{H}, d, J=7.6 \mathrm{~Hz})$, 
indicating the presence of two $\beta$-anomers in the sugar moiety. The ${ }^{1} \mathrm{H}$ - and ${ }^{13} \mathrm{C}-\mathrm{NMR}$ spectra of 8 indicated that it was a $\beta$-gentiobiosyl analogue of 5 . Furthermore, the HMBC spectrum included correlations between the anomeric proton signal at $\delta 5.12\left(\mathrm{H}-1^{\prime \prime}\right)$ and the carbon signal at $\delta 152.5(\mathrm{C}-7)$, and between the anomeric proton signal at $\delta 4.50$ (H-1"') and the carbon signal at $\delta 68.9(\mathrm{C}-6 ")$. These findings confirm that the inner $\beta$-D-glucopyranosyl residue was attached to the phenolic hydroxyl group at C-7 of glycitein (5) and that the pair of $\beta$-D-glucopyranosyl residues were 1,6-linked. Thus, the product 8 was identified as glycitein 7-O-[6- $O$ - $(\beta$-D-glucopyranosyl)]- $\beta$-D-glucopyranoside (7-O- $\beta$-gentiobioside).

Figure 1. Synthesis of $\beta$-gentiooligosaccharides of genistein (1) and glycitein (5) by glycosylation with E. perriniana.

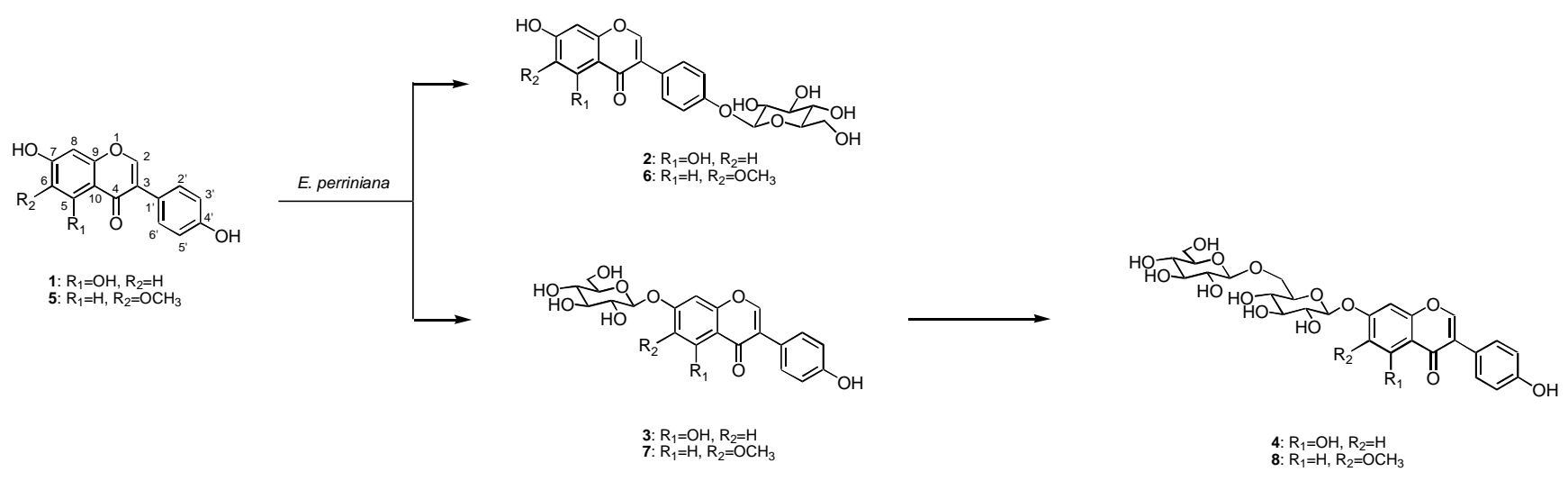

\subsection{Radical Scavenging Activity of $\beta$-Glycosides of Genistein and Glycitein}

The DPPH free-radical scavenging activity of genistein $\beta$-glycosides 2-4 and glycitein $\beta$-glycosides 6-8 was determined by in vitro bioassay. The antioxidant activities were expressed as $\mathrm{IC}_{50}$ values and are summarized in Table 1. Genistein 4'-O- $\beta$-D-glucoside (2), genistein 7- $O$ - $\beta$-D-glucoside (3), glycitein 4'-O- $\beta$-D-glucoside (6), and glycitein 7-O- $\beta$-D-glucoside (7) showed DPPH free-radical scavenging activity. On the other hand, the $\beta$-gentiobiosides of genistein and glycitein (4 and 8 ) had no antioxidant activity. The results obtained here suggested that mono-glucosides of genistein and glycitein would be useful free-radical scavenging antioxidants with aqueous-solubility.

The superoxide-radical scavenging activity of genistein $\beta$-glycosides $\mathbf{2 - 4}$ and glycitein $\beta$-glycosides 6-8 was expressed as $\mathrm{IC}_{50}$ values summarized in Table 1 . Genistein 4'- $O$ - $\beta$-D-glucoside (2), genistein 7- $O$ - $\beta$-D-glucoside (3), glycitein 4'-O- $\beta$-D-glucoside (6), and glycitein 7- $O$ - $\beta$-D-glucoside (7) showed superoxide-radical scavenging activity. The present data demonstrated that gentiobiosylation of isoflavones drastically reduced the antioxidant activity in comparison with isoflavone glucosides. A recent paper reported that glycitein 7-O-maltotrioside showed no antioxidant activity, although glycitein 7-O-glucoside exerted relatively high antioxidant activity, and that maltosylation at $\mathrm{C}-7$ of glycitein also reduced the antioxidant activity in comparison with glycitein 7-O-glucoside [13].

These suggest that formation of long oligosaccharide chains attached to isoflavones might reduce their antioxidant activity. In addition, gentiobioside compounds which contains one phenolic hydroxyl group in their molecule, i.e., salicifolioside A, have been reported to show no DPPH free-radical scavenging activity [14]. It is postulated that gentiobiosylation might eliminate the antioxidant activity 
of aglycones. The results obtained here suggested that mono-glucosides of genistein and glycitein would be potential superoxide-radical scavenging antioxidants. Further studies on Trolox equivalent antioxidant capacity (TEAC) of the glycosides are now in progress.

Table 1. Antioxidant activities of genistein $\beta$-glycosides 2-4 and glycitein $\beta$-glycosides 6-8.

\begin{tabular}{lcc}
\hline \multirow{2}{*}{ Compound } & \multicolumn{2}{c}{$\mathbf{I C}_{\mathbf{5 0}}(\boldsymbol{\mu} \mathbf{M})$} \\
\cline { 2 - 3 } & DPPH free-radical scavenging & Superoxide-radical scavenging \\
\hline $\mathbf{2}$ & 52 & 751 \\
$\mathbf{3}$ & 49 & 704 \\
$\mathbf{4}$ & $>200$ & $>1000$ \\
$\mathbf{6}$ & 55 & 764 \\
$\mathbf{7}$ & 51 & 708 \\
$\mathbf{8}$ & 162 & $>1000$ \\
Vitamin C & 35 & 698 \\
\hline
\end{tabular}

\subsection{Anti-Allergic Activity of $\beta$-Glycosides of Genistein and Glycitein}

The effects of genistein $\beta$-glycosides 2-4 on IgE antibody formation were examined by an in vivo bioassay using $7 \mathrm{~S}$-globulin from soybean as an antigen. The average of rat plasma IgE level after treatment of 7S-globulin with or without test compounds is summarized in Table 2. Genistein 7-O- $\beta$-D-glucoside (3) showed inhibitory action on $\operatorname{IgE}$ antibody generation. On the other hand, genistein 4'- $O$ - $\beta$-D-glucoside (2) and genistein 7- $O$ - $\beta$-gentiobioside (4) did not exhibit the inhibitory action on $\operatorname{IgE}$ antibody formation.

Table 2. Suppressive action of genistein and glycitein and their $\beta$-glycosides 1-8 on IgE antibody formation.

\begin{tabular}{ll}
\hline Compound & IgE level $^{\mathbf{a}}$ \\
\hline None & 401.7 \\
$\mathbf{1}$ & 145.1 \\
$\mathbf{2}$ & 452.2 \\
$\mathbf{3}$ & 168.5 \\
$\mathbf{4}$ & 466.2 \\
$\mathbf{5}$ & 135.9 \\
$\mathbf{6}$ & 383.8 \\
$\mathbf{7}$ & 151.0 \\
$\mathbf{8}$ & 256.6 \\
Hydrocortisone & 342.0 \\
\hline
\end{tabular}

${ }^{a}$ The results were expressed as average of plasma IgE level of seven rats administered a total of $10 \mathrm{mg} / \mathrm{kg}$ of each test compound.

Next, the average of rat plasma IgE level after treatment of 7S-globulin with or without glycitein $\beta$-glycosides 6-8 was examined. Glycitein 7-O- $\beta$-D-glucoside (7) and glycitein 7- $O$ - $\beta$-gentiobioside (8) showed inhibitory action on IgE antibody formation. The 4'-O- $\beta$-D-glucoside (6) of glycitein did not inhibit IgE antibody generation (Table 2).

Recently, we reported that 7-O- $\beta$-glycosides of genistein and quercetin showed anti-allergic activity, i.e., suppressive action on histamine release from rat peritoneal mast cells, whereas the $\beta$-glycosides, 
the sugar of which attached at other phenolic hydroxyl groups, exhibited no anti-allergic actions [15]. The results obtained here suggested that $\beta$-glucoside and $\beta$-gentiobioside at C-7 of genistein and/or glycitein did not attenuate the anti-allergic activity, and that phenolic hydroxyl groups at 4'-position might be necessary for the anti-allergic action of glycosides of genistein and glycitein. Further studies on the mechanism of $\beta$-glycosides of genistein and glycitein to act as anti-allergic formulations are now in progress.

\section{Experimental Section}

\subsection{General}

Genistein and glycotein were purchased from Sigma-Aldrich Co. The NMR spectra were recorded in DMSO- $d_{6}$ using a Varian XL-400 spectrometer. The chemical shifts were expressed in $\delta(\mathrm{ppm})$ referring to tetramethylsilane. The HRFABMS spectra were measured using a JEOL MStation JMS-700 spectrometer. HPLC was carried out on a YMC-Pack R\&D ODS column $(150 \times 30 \mathrm{~mm})$ [solvent: $\mathrm{CH}_{3} \mathrm{CN}: \mathrm{H}_{2} \mathrm{O}(3: 17, \mathrm{v} / \mathrm{v})$; detection: $\mathrm{UV}(280 \mathrm{~nm})$; flow rate: $1.0 \mathrm{~mL} / \mathrm{min}$ ].

\subsection{Cultured Cells and Culture Conditions}

A cell culture of E. perriniana was induced in our laboratory, and has been cultivated for over 20 years [16]. Cultured E. perriniana cells were subcultured at 4-week intervals on solid Murashige and Skoog (MS) medium (100 mL in a 300-mL conical flask) containing 3\% sucrose, $10 \mathrm{mM}$ 2,4-dichlorophenoxyacetic acid, and $1 \%$ agar (adjusted to $\mathrm{pH} 5.7$ ) at $25{ }^{\circ} \mathrm{C}$ in the dark. A suspension culture was started by transferring the cultured cells to $100 \mathrm{~mL}$ of liquid medium in a $300-\mathrm{mL}$ conical flask, and incubated on a rotary shaker $(120 \mathrm{rpm})$ at $25{ }^{\circ} \mathrm{C}$ in the dark. Prior to use for this work, part of the callus tissues (fr. wt $40 \mathrm{~g}$ ) was transplanted to freshly prepared MS medium (100 mL in a $300-\mathrm{mL}$ conical flask) and grown with continuous shaking for 2 weeks on a rotary shaker (120 rpm).

\subsection{Production of $\beta$-Glycosides of Genistein and Glycitein by E. perriniana}

Substrate $(0.08 \mathrm{mmol})$ dissolved in $\mathrm{EtOH}(300 \mu \mathrm{L})$ was individually administered to a 500 -mL flask containing suspension cultured cells of E. perriniana. The cultures were then incubated at $25^{\circ} \mathrm{C}$ for five days on a rotary shaker $(120 \mathrm{rpm})$ in the dark. After incubation, the cells and medium were separated by filtration with suction. The filtered medium was extracted with EtOAc. The medium was further extracted with $n-\mathrm{BuOH}$. EtOAc and $n$ - $\mathrm{BuOH}$ fractions were analyzed by HPLC The cells were extracted with $\mathrm{MeOH}$ for $12 \mathrm{~h}$ and sonicated for $5 \mathrm{~min}$. The yields of the glycosylation products were calculated on the basis of the peak area from HPLC using calibration curves prepared by HPLC analyses of the authentic glycosides. The $\mathrm{MeOH}$ fraction was conc. and partitioned between $\mathrm{H}_{2} \mathrm{O}$ and EtOAc. The EtOAc fractions were combined and analyzed by the HPLC. The $\mathrm{H}_{2} \mathrm{O}$ fraction was applied to a Diaion HP-20 column and the column was washed with $\mathrm{H}_{2} \mathrm{O}$ followed by elution with $\mathrm{MeOH}$. The $\mathrm{MeOH}$ eluate was subjected to HPLC [column: YMC-Pack R\&D ODS column $(150 \times 30 \mathrm{~mm})$; solvent: $\mathrm{MeOH}-\mathrm{H}_{2} \mathrm{O}(9: 11, \mathrm{v} / \mathrm{v})$; detection: $\mathrm{UV}(280 \mathrm{~nm})$; flow rate: $\left.1.0 \mathrm{~mL} / \mathrm{min}\right]$ to give glycosylated products. Spectral data of new compounds are as follows. 
Genistein 7-O- $\beta$-gentiobioside (4): IR ( $\left.v_{\max }\right)$ : 3417, 1655, 1612, 1582, 1510, 1495, 1360, 1241; HRFABMS: $m / z$ 617.1488 [M + Na $]^{+}$(calc. for $\left.\mathrm{C}_{27} \mathrm{H}_{30} \mathrm{O}_{15} \mathrm{Na}, 617.1482\right)$ ) ${ }^{1} \mathrm{H}-\mathrm{NMR}: \delta$ 3.15-3.70 (12H, m, H-2", 2"', 3", 3"', 4", 4"', 5", 5"', 6", 6"'), 4.25 (1H, d, J=8.0 Hz, H-1"'), 5.10 (1H, d, J= 7.6 Hz, H-1"), 6.51 (1H, d, $J=2.0 \mathrm{~Hz}, \mathrm{H}-6), 6.70$ (1H, d, $J=2.0 \mathrm{~Hz}, \mathrm{H}-8), 6.90$ (2H, d, $\left.J=6.4 \mathrm{~Hz}, \mathrm{H}-3^{\prime}, 5^{\prime}\right)$, $7.51\left(2 \mathrm{H}, \mathrm{d}, J=6.4 \mathrm{~Hz}, \mathrm{H}-2^{\prime}, 6^{\prime}\right), 8.40(1 \mathrm{H}, \mathrm{s}, \mathrm{H}-2) ;{ }^{13} \mathrm{C}-\mathrm{NMR}: \delta 60.8$ (C-6"'), 68.6 (C-6"), 69.2 (C-4"'), 69.8 (C-4"), 72.7 (C-2'"), 73.3 (C-2"), 75.9 (C-5"'), 76.3 (C-5"), 76.4 (C-3"'), 76.9 (C-3"), 99.5 (C-1"), 100.2 (C-8), 102.8 (C-1"'), 101.6 (C-6), 106.0 (C-10), 115.0 (C-3', C-5'), 122.1 (C-1'), 124.1 (C-3), 130.2 (C-2', C-6'), 153.5 (C-2), 156.2 (C-4'), 157.5 (C-9), 160.2 (C-5), 163.0 (C-7), 178.0 (C-4). Anal. Calcd for $\mathrm{C}_{27} \mathrm{H}_{30} \mathrm{O}_{15}$ : C, 52.54; H, 4.90. Found: C, 52.45; H, 4.85.

Glycitein 7-O- $\beta$-genitiobioside (8): IR ( $\left.v_{\max }\right)$ : 3410, 1651, 1611, 1577, 1510, 1490, 1362, 1235; HRFABMS $m / z$ : $631.1645[\mathrm{M}+\mathrm{Na}]^{+}$(calcd 631.1639 for $\mathrm{C}_{28} \mathrm{H}_{32} \mathrm{O}_{15} \mathrm{Na}$ ); ${ }^{1} \mathrm{H}-\mathrm{NMR}: \delta$ 3.09-3.72 $(12 \mathrm{H}$, m, H-2", 2"', 3", 3"', 4", 4"', 5", 5"', 6", 6"'), 3.90 (3H, s, OCH $), 4.50$ (1H, d, J= 7.6 Hz, H-1"'), 5.12 (1H, d, $\left.J=7.6 \mathrm{~Hz}, \mathrm{H}-1^{\prime \prime}\right), 7.04$ (2H, d, $\left.J=8.0 \mathrm{~Hz}, \mathrm{H}-3^{\prime}, 5^{\prime}\right), 7.46$ (1H, s, H-8), 7.51 (2H, d, $J=8.0 \mathrm{~Hz}, \mathrm{H}-2^{\prime}$, 6'), $7.76(1 \mathrm{H}, \mathrm{s}, \mathrm{H}-5), 8.41(1 \mathrm{H}, \mathrm{s}, \mathrm{H}-2)$; ${ }^{13} \mathrm{C}-\mathrm{NMR}: \delta 56.1\left(\mathrm{OCH}_{3}\right), 60.5$ (C-6"'), 68.9 (C-6"), 69.5 (C-4"'), 69.9 (C-4"), 72.9 (C-2"'), 73.3 (C-2"), 75.7 (C-5"'), 76.7 (C-5"), 76.8 (C-3"'), 77.0 (C-3"), 99.0 (C-1"), 101.9 (C-1"'), 101.0 (C-8), 105.1 (C-5), 115.1 (C-3', C-5'), 117.6 (C-10), 122.5 (C-1'), 124.5 (C-3), 130.3 (C-2', C-6'), 148.8 (C-6), 151.0 (C-9), 152.5 (C-7), 153.5 (C-2), 157.0 (C-4'), 178.0 (C-4). Anal. Calcd for $\mathrm{C}_{28} \mathrm{H}_{32} \mathrm{O}_{15}$ : C, 53.28; H, 5.11. Found: C, 53.25; H, 5.01.

\subsection{DPPH Radical Scavenging Activity}

DPPH free-radical scavenging activities of $\beta$-glycosides of genistein and glycotein were determined as follows: DPPH was dissolved in ethanol $(500 \mu \mathrm{M})$ [17]. The sample solutions were prepared by dissolving each compound in ethanol. To solutions containing various concentrations of each sample $(0.1 \mathrm{~mL})$ and ethanol $(0.9 \mathrm{~mL})$ was added DPPH solution $(1 \mathrm{~mL})$ at room temperature. Vitamin $\mathrm{C}$ was used as a positive control. After $20 \mathrm{~min}$ at $25{ }^{\circ} \mathrm{C}$, the absorbance was measured at $517 \mathrm{~nm}$. The percentage reduction of the initial DPPH adsorption, i.e., the free-radical scavenging activity, was calculated as follows: $\mathrm{E}=\left[\left(A_{\mathrm{c}}-A_{\mathrm{t}}\right) / A_{\mathrm{c}}\right] \times 100$, where $A_{\mathrm{t}}$ and $A_{\mathrm{c}}$ are the respective absorbance at $517 \mathrm{~nm}$ of sample solutions with and without the test compounds. Antioxidant activity was expressed as the $50 \%$ inhibitory concentration $\left(\mathrm{IC}_{50}\right)$.

\subsection{Superoxide-Radical Scavenging Activity}

Superoxide was generated by the xanthine-xanthine oxidase system [17]. Reaction mixture contained $4 \mathrm{mM}$ xanthine $(50 \mu \mathrm{L})$, various concentration of sample in ethanol $(50 \mu \mathrm{L}), 2 \mathrm{mM}$ nitro blue tetrazolium (NBT, $50 \mu \mathrm{L}), 0.3 \mathrm{nkat} / \mathrm{mL}$ xanthine oxidase $(50 \mu \mathrm{L})$, and $0.1 \mathrm{M}$ phosphate buffer ( $\mathrm{pH} 7.4)$ in a total volume of $2 \mathrm{~mL}$. Vitamin $\mathrm{C}$ was used as a positive control. The reaction mixture was incubated at $25{ }^{\circ} \mathrm{C}$ for $10 \mathrm{~min}$ and the absorbance was read at $560 \mathrm{~nm}$. Percent inhibition was calculated by comparing with control without test compound but containing the same amount of alcohol. The $\mathrm{IC}_{50}$ value is shown as the sample concentration at which $50 \%$ of superoxide-radical was scavenged. 


\subsection{Suppressive Action on IgE Antibody Formation}

The inhibitory action of $\beta$-glycosides of genistein and glycotein on $\operatorname{IgE}$ antibody formation was examined as follows. 7S-Globulin was used as the antigen $(1 \mathrm{mg} / \mathrm{rat})$, and $\mathrm{Al}(\mathrm{OH})_{3}$ and pertussis vaccine were used as the adjuvants ( $20 \mathrm{mg}$ and $0.6 \mathrm{~mL} / \mathrm{rat}$, respectively). Sensitization was made by injection of a mixture $(0.6 \mathrm{~mL})$ of the antigen and the adjuvant into the paws of each rat (male, ca. $200 \mathrm{~g}$ ). Paw edema was measured $24 \mathrm{~h}$ after injection and the treated rats were divided in groups with an equal average swelling volume. Each sample was dissolved in physiological saline containing 10\% Nikkol and the solution was injected daily into the rat for $11 \mathrm{~d}$ starting on the day of grouping. Hydrocortisone was used as the positive control. The amount of $\operatorname{IgE}$ was measured by the passive cutaneous anaphylaxis method on the 15th day [18]. The results were expressed as average of plasma IgE level of 7 rats administered a total of $10 \mathrm{mg} / \mathrm{kg}$ of each test compound.

\section{Conclusions}

The gentiooligosaccharides of genistein and glycitein were successfully produced by biocatalytic glycosylation with cultured cells of $E$. perriniana. The $\beta$-glucosides of genistein and glycitein showed DPPH free-radical scavenging activity and superoxide-radical scavenging activity. On the other hand, 7-O- $\beta$-glucosides of genistein and glycitein, and 7-O- $\beta$-gentiobioside of glycitein exerted inhibitory effects on IgE antibody production.

\section{Acknowledgments}

This work was supported by grant from the Iijima Memorial Foundation for The Promotion of Food Science and Technology.

\section{Conflict of Interest}

The authors declare no conflict of interest.

\section{References and Notes}

1. Adlercreutz, H.; Goldin, B.R.; Gorbach, S.L.; Höckerstedt, K.A.V.; Watanabe, S. Soybean phytoestrogen intake and cancer risk. J. Nutr. 1995, 125, 757-770.

2. Barnes, S. Evolution of the health benefits of soy isoflavones. Proc. Soc. Exp. Biol. Med. 1998, 217, 386-392.

3. Marotta, F.; Mao, G.S.; Liu, T.; Chui, D.H.; Lorenzetti, A.; Xiao, Y.; Marandola, P. Anti-inflammatory and neuroprotective effect of a phytoestrogen compound on rat microglia. Ann. N.Y. Acad. Sci. 2006, 1089, 276-281.

4. Setchell, K.D.R.; Cassidy, A. Dietary isoflavones: Biological effects and relevance to human health. J. Nutr. 1999, 129, 758S-767S.

5. Chacko, B.K.; Chandler, R.T.; D’Alessandro, T.L.; Mundhekar, A.; Khoo, N.K.; Botting, N.; Barnes, S.; Patel, R.P. Anti-inflammatory effects of isoflavones are dependent on flow and human endothelial cell PPARgamma. J. Nutr. 2007, 137, 351-356. 
6. Shimoda, K.; Kondo, Y.; Nishida, T.; Hamada, H.; Nakajima, N.; Hamada, H. Biotransformation of thymol, carvacrol, and eugenol by cultured cells of Eucalyptus perriniana. Phytochemistry 2006, 67, 2256-2261.

7. Shimoda, K.; Kwon, S.; Utsuki, A.; Ohiwa, S.; Katsuragi, H.; Yonemoto, N.; Hamada, H.; Hamada, H. Glycosylation of capsaicin and 8-nordihydrocapsaicin by cultured cells of Catharanthus roseus. Phytochemistry 2007, 68, 1391-1396.

8. Shimoda, K.; Kubota, N.; Kondo, Y.; Sato, D.; Hamada, H. Glycosylation of fluorophenols by plant cell cultures. Int. J. Mol. Sci. 2009, 10, 1942-1949.

9. Shimoda, K.; Akagi, M.; Hamada, H. Production of $\beta$-maltooligosaccharides of $\alpha$ - and $\delta$-tocopherols by Klebsiella pneumoniae and cyclodextrin glucanotransferase as anti-allergic agents. Molecules 2009, 14, 3106-3114.

10. Shimoda, K.; Hamada, H. Production of hesperetin glycosides by Xanthomonas campestris and cyclodextrin glucanotransferase and their anti-allergic activities. Nutrients 2010, 2, 171-180.

11. Shimoda, K.; Kubota, N.; Taniuchi, K.; Sato, D.; Nakajima, N.; Hamada, H.; Hamada, H. Biotransformation of naringin and naringenin by cultured Eucalyptus perriniana cells. Phytochemistry 2010, 71, 201-205.

12. Morand, C.; Manach, C.; Crespy, V.; Remesy, C. Quercetin 3-O-beta-glucoside is better absorbed than other quercetin forms and is not present in rat plasma. Free Radic. Res. 2000, 33, 667-676.

13. Shimoda, K.; Hamada, H. Synthesis of $\beta$-maltooligosaccharides of glycitein and daidzein and their anti-oxidant and anti-allergic activities. Molecules 2010, 15, 5153-5161.

14. Calis, I.; Kuruuzum, A.; Demirezer, O.; Sticher, O.; Ganci, W.; Ruedi, P. Phenyl valeric acid and flavonoid glycosides from Polygonum salicifolium. J. Nat. Prod. 1999, 62, 1101-1105.

15. Shimoda, K.; Kobayashi, T.; Akagi, M.; Hamada, H.; Hamada, H. Synthesis of oligosaccharides of genistein and quercetin as potential anti-inflammatory agents. Chem. Lett. 2008, 37, 876-877.

16. Furuya, T.; Orihara, Y.; Hayashi, C. Triterpenoids from Eucalyptus perriniana cultured cells. Phytochemistry 1987, 26, 715-719.

17. Ozsoy, N.; Candoken, E.; Akev, N. Implications for degenerative disorders: Antioxidative activity, total phenols, flavonoids, ascorbic acid, $\beta$-carotene and $\beta$-tocopherol in Aloe vera. Oxid. Med. Cell Longev. 2009, 2, 99-106.

18. Koda, A.; Miura, T.; Inagaki, N.; Sakamoto, O.; Arimura, A.; Nagai, H.; Mori, H. A method for evaluating anti-allergic drugs by simultaneously induced passive cutaneous anaphylaxis and mediator cutaneous reactions. Int. Arch. Allergy. Appl. Immunol. 1990, 92, 209-216.

Sample Availability: Not available.

(C) 2011 by the authors; licensee MDPI, Basel, Switzerland. This article is an open access article distributed under the terms and conditions of the Creative Commons Attribution license (http://creativecommons.org/licenses/by/3.0/). 